\title{
Eocene sedimentary facies in a volcanogenic succession on King George Island, South Shetland Islands: a record of pre-ice sheet terrestrial environments in West Antarctica
}

\author{
Anna MOZER ${ }^{1, *}$ \\ 1 Institute of Geological Sciences, Polish Academy of Sciences, Twarda 51/55, 00-818 Warszawa, Poland
}

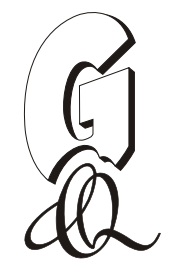

Mozer A. (2013) Eocene sedimentary facies in a volcanogenic succession on King George Island, South Shetland Islands: a record of pre-ice sheet terrestrial environments in West Antarctica. Geological Quarterly, 57 (3): 385-394, doi: $10.7306 / \mathrm{gq} .1100$

\begin{abstract}
About $34 \mathrm{Ma}$ ago there was a radical change of climate that led to the formation of Antarctic ice sheet. King George Island, located in the South Shetland Islands volcanic arc (northern Antarctic Peninsula region), is one of a few places in West Antarctica which shows a geological record of sedimentary environments preceding the development of the ice sheet. The Eocene sedimentary facies occur in the dominantly volcanogenic succession of King George Island. They have been recognized in the Arctowski Cove and Point Thomas formations (Ezcurra Inlet Group) and in the Mount Wawel Formation (Point Hennequin Group) in Admiralty Bay, and in the Mazurek Point Formation (Chopin Ridge Group) and Lions Cove Formation (Polonia Glacier group) in King George Bay. They record a cooling trend in terrestrial environments that began at termination of the Early/Middle Eocene Climatic Optimum, and was followed by a significant deterioration of climate during Late Eocene and earliest Oligocene, directly preceding glacial conditions in the northern Antarctic Peninsula region. The ongoing research confirms the existence of three preglacial climatic stages (PGS-1-PGS-3) during Eocene-earliest Oligocene, from humid, warm to moderate climate (PGS-1), through cool and dry climate (PGS-2), up to cold and humid conditions (PGS-3). Studies were carried out on usually fine-grained volcanoclastic sediments, containing Podocarpaceae-Araucaria-Nothofagus plant fossil assemblies. Beds of reworked pyroclastic material alternate with lava flows or volcanic agglomerates, as well as ex situ blocks of Eocene volcanogenic sediments on a moraine. Calculated geochemical indices of weathering (CIA, PIA and CIW) confirm moderate to high chemical weathering under warm and humid climate conditions at the beginning and deterioration of conditions in the end of Eocene.
\end{abstract}

Key words: Antarctica, King George Island, Eocene, preglacial environments, plant fossils.

\section{INTRODUCTION}

Actual patterns of climate cooling during the Late Eocene and the causes of permanent and stable glaciation are still far from being understood, but there are clues from the sedimentary record of Antarctica that help interpret this greenhouse-icehouse transition (Zachos et al., 2001, 2003). Geological evidence from rocks and fossils from the Antarctic Peninsula region provide sparse clues about cooling Cenozoic climates in the terrestrial realm (Askin and Spicer, 1995; Dutra, 2001; Francis and Poole, 2002; Francis et al., 2008). The stratigraphic sequence exposed on King George Island (KGI), South Shetland Islands, West Antarctica (Fig. 1A) spans the Late Cretaceous to Early Miocene. It is composed of terrestrial lavas, pyroclastic and volcaniclastic sediments of a variety of grain sizes, often with plant macrofossils, cut by younger intrusions and dykes. The highest part of the lithostratigraphic column of $\mathrm{KGI}$ is composed of marine and glaciomarine sediments. This

\section{*E-mail: amozer@twarda.pan.pl}

Received: July 3, 2012; accepted: February 25, 2013; first published online: May 23, 2013 sequence provides important details that record environmental conditions on land during the Early and Middle Paleogene, directly preceding ice sheet development on the Antarctic continent. The climatic trend that the succession reveals can be correlated with an oceanic record of Antarctic climate evolution based on a compilation of oxygen isotope analyses and benthic foraminifera (Zachos et al., 2001, 2003, 2008).

This paper analyses sedimentary sequences bearing plant macrofossils that crop out in several sites located on the southern part of KGI that are considered Eocene in age. They are evidence for the presence, diversity and extinction of terrestrial vegetation in the northern Antarctic Peninsula region during this time. Palaeoecological interpretations, from facies and palaeobotanical analyses suggest far-reaching climate change including recognition of three preglacial palaeoclimatic stages.

\section{EVOLUTION OF EOCENE CLIMATE IN ANTARCTIC PENINSULA AREA}

The Cenozoic cooling trend followed the Paleocene/Eocene Thermal Maximum (PETM) and included a short-lived warm period during the Early/Middle Eocene Climatic Optimum. Further significant cooling during the Late Eocene and earliest 


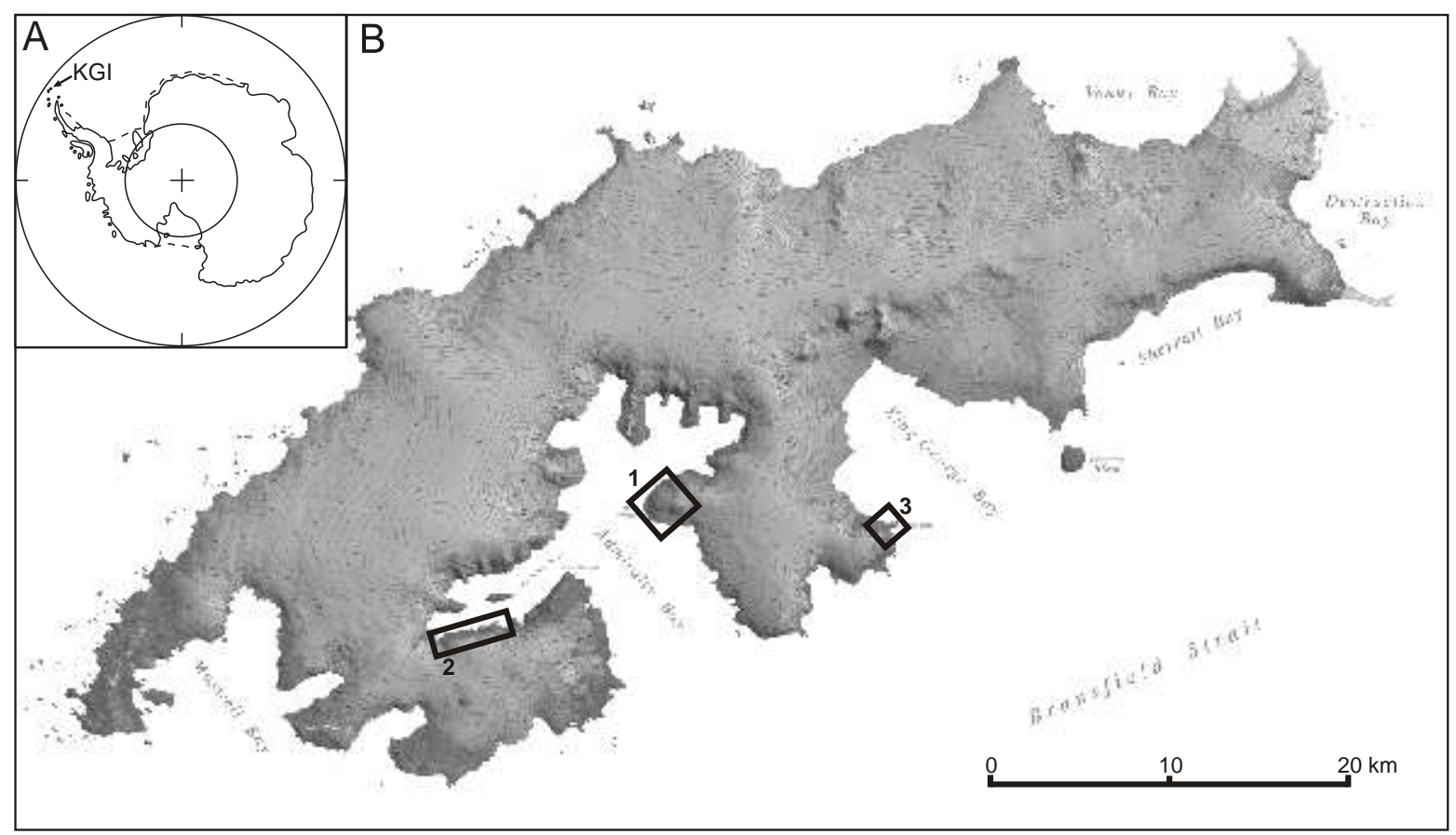

Fig. 1A - location of King George Island in Antarctica; B - topographic map of King George Island, with location of described outcrops: 1 - Mount Wawel - Dragon Glacier Moraine, 2 - Cytadela, 3 - Lions Rump - Conglomerate Bluff (based on Topographic Map, 2001)

Oligocene, directly preceded glacial conditions in Antarctica (Zachos et al., 2001, 2003). Cenozoic global climates were generally controlled by tectonism, that occurred in southern mid- to high latitudes, culminating in the isolation of Antarctica, inception of the Antarctic Circumpolar Current, development of the modern Southern Ocean, build-up of Antarctic ice and deterioration into icehouse conditions (Kennett and Baker, 1990 and references therein; Francis et al., 2009; Sijp et al., 2009). The geological record exposed on land is confined to a few outcrops located in the northern Antarctic Peninsula region. Rich terrestrial floras preserved in Eocene sediments of this region provide significant clues about Cenozoic climate change. Several authors have used various biotic components to reconstruct depositional and climatic conditions during the accumulation of the sedimentary sequences: wood (Lucas and Lacey, 1981; Francis and Poole, 2002), leaves imprint (Zastawniak, 1981, 1990, 1998; Zastawniak et al., 1985; Birkenmajer and Zastawniak, 1986, 1989a, b; Li, 1992; Dutra, 2001, 2004; Hunt and Poole, 2003; Kellner et al., 2007; Fontes and Dutra, 2010), plant and fish assemblage (Doktor et al., 1996), wood, tree-ring and palynomorph set together (Askin and Spicer, 1995; Duan and Cao, 1998; Francis et al., 2008; Panti et al., 2012). The terrestrial floras confirmed a warm (i.e., frost-free) Eocene climate with a general cooling trend up the succession, culminating in a significant cooling during the Late Eocene.

\section{METHODS}

The material analysed in this paper (volcanic and sedimentary rocks and plant macrofossils) were collected from a thick volcanic and volcaniclastic succession exposed within the Admiralty Bay and King George Bay areas, on King George Island (Fig. 1B).

Petrographic observations of volcanic and sedimentary rocks were made using thin sections under transmitted and reflected light microscopy (TLM and RLM respectively) and scan- ning electron microscopy (SEM). A JEOL JXA 840A scanning electron microscope operating at a $15 \mathrm{kV}$ accelerating voltage was used. Quantitative Energy-Dispersive Spectroscopy (EDS) analyses of pyrite were obtained using the same microscope, equipped with a Thermo Noran Vantage EDS system. Operating conditions were a $15 \mathrm{kV}$ acceleration voltage, 1 to $5 \mu \mathrm{m}$ beam diameter, and $100 \mathrm{~s}$ counting time. Detection limits of the analysed elements (S, Fe, Co, $\mathrm{Ni}, \mathrm{Cu}, \mathrm{Zn}$ ) were better than 0.05 wt.\%.

The X-ray diffraction analysis (XRD) was undertaken on powdered whole-rock samples. The rock samples were crushed and powdered to the 5-10 $\mu \mathrm{m}$ fraction. X-ray diffraction patterns were recorded on a SIGMA 2070 diffractometer using a curved position sensitive detector in the range $2-120^{\circ} 2 \Theta$ with CoK $\alpha$ radiation and 20 hour analysis time. Diffractione/ software v. $03 / 93$ was used to process the data obtained.

Geochemical analysis was undertaken on the same rock samples. The basis for these analyses were Inductively Coupled Plasma Emission Spectrometry (ICP-ES) and Inductively Coupled Plasma Mass Spectrometry (ICP-MS) results provided by Acme Labs, Canada. Results obtained were subject to mathematical processing which enabled detailing data collection of the molar content of elements and enrichment factors, related to volcanic bedrock. These data were used to calculate weathering indices, such as the Chemical Index of Alternation (CIA), Chemical Index of Weathering (CIW) and Plagioclase Index of Alternation (PIA). The most popular chemical index to quantify the degree of source-area weathering is $\mathrm{CIA}$, proposed by Nesbitt and Young (1982). This index is defined as: $\mathrm{CIA}=$ $\left[\mathrm{Al}_{2} \mathrm{O}_{3} /\left(\mathrm{Al}_{2} \mathrm{O}_{3}+\mathrm{CaO}^{*}+\mathrm{Na}_{2} \mathrm{O}+\mathrm{K}_{2} \mathrm{O}\right)\right] \times 100$, in molecular proportions, where $\mathrm{CaO}^{*}$ is the amount of $\mathrm{CaO}$ incorporated in silicates. This index gives a practical approach to the measurement of feldspar transformation to clay minerals and the influence of weathering increases with increasing values of $\mathrm{CIA}$. An alternative chemical index to the CIA was proposed by Harnois (1988) and termed the chemical index of weathering (CIW). It eliminates $\mathrm{K}_{2} \mathrm{O}$ from the equation, which is defined as follows: $\mathrm{CIW}=\left[\mathrm{Al}_{2} \mathrm{O}_{3} /\left(\mathrm{Al}_{2} \mathrm{O}_{3}+\mathrm{CaO}^{*}+\mathrm{Na}_{2} \mathrm{O}\right)\right] \times 100$, where the oxides 
are in molar proportions, and $\mathrm{CaO}^{*}$ is the amount of $\mathrm{CaO}$ in silicates. The third index used to describe the degree of chemical weathering is PIA, defined by Fedo et al. (1995) as:

$\mathrm{PIA}=\left[\left(\mathrm{Al}_{2} \mathrm{O}_{3}-\mathrm{K}_{2} \mathrm{O}\right) /\left(\mathrm{Al}_{2} \mathrm{O}_{3}+\mathrm{CaO}^{*}+\mathrm{Na}_{2} \mathrm{O}-\mathrm{K}_{2} \mathrm{O}\right)\right] \times 100$, where $\mathrm{CaO}^{*}$ is the $\mathrm{CaO}$ residing only in the silicate fraction.

Moreover, all the collected macrofossils flora, which preserved at least basic anatomical features, have been the subject of qualitative identification. Plant remains were collected from lose blocks (Mount Wawel Formation) and in situ sites (Point Thomas Formation and Lions Cove Formation). Leaf identification was carried out based on available palaeobotanical literature that concerning Cenozoic plant remains known from Antarctica, South America and Australia, and with assistance of Professor E. Zastawniak-Birkenmajer. All macrofossils flora samples analysed in this paper have rich photographic documentation and are housed at the Institute of Geological Sciences, Polish Academy of Sciences, in Warszawa.

\section{RESULTS}

Eocene volcanic and volcaniclastic successions, which were deposited in a fore-arc setting, and are exposed in the Admiralty Bay and King George Bay areas (Elliot, 1988), were explored. These sequences are dominated by alternating lava flows and pyroclastic material of different grain size (from blocks to very fine sand) and levels of reworked sediments (clasts and tuffites) containing plant detritus. The majority of information concerning preglacial climate and palaeoenvironmental conditions are derived from sediments deposited during breaks in volcanic activity, i.e. between horizons of lavas.

\section{ADMIRALTY BAY AREA - MOUNT WAWEL LOCALITY}

In the Admiralty Bay area, the Mount Wawel Formation (Point Hennequin Group) contains a very rich assemblage of plant macrofossils, which provides information about probable Middle Eocene environments. The clastic facies of the Mount Wawel Formation is enriched in authigenic pyrite (Fig. 2A), which occurs mostly in the form of framboids associated with pyritized plant debris (Mozer, 2010). The framboids are sphaeroidal to sub-sphaeroidal in shape and are composed of densely packed microcrystals. Pyritic microcapsules associated with pyrite framboids showing empty interiors and apertures open towards the pore space (Fig. 2B). Plant remains and the associated authigenic pyrite occur in fine-grained rocks, mostly in grey and greyish-brown mudstones, siltstones and claystones, which contain small-sized volcanic bombs (up to a few centimetres in size) and scattered finer volcanigenic clasts (Fig. 2C). Almost all loose blocks observed at the moraine reveal stratification emphasized by vertical changes in grain size, as well as by the horizontal alignment of plant remains. Sediments also contain levels of reworked pyroclastic material which builds sedimentary structures like small-scale cross bedding (Fig. 2D). Surfaces with asymmetrical wave ripples were found on bedding planes of the loose blocks on the moraine also (Fig. 2E, F).

In most cases the clastic material is dominated by recrystallized brown and green volcanic glass, lithoclasts, some plagioclases and relatively large pyroxene crystals (Fig. 3). X-ray analyses (not presented here) confirm the presence of pyroxene, which suggests only short transport of clastic material.

Macroflora deposits that had originated from an individual locality named Dragon Glacier Moraine, were known and had been described (Zastawniak, 1981; Zastawniak et al., 1985; Fontes and Dutra, 2010). Leaf imprints are the predominant plant remains visible in tuffaceous rocks. The plant assemblage is composed of Equisetum (horsetail), ferns, several Nothofagus species and other angiosperms and Podocarpaceae (Fig. 4A-I). Nothofagus leaves are easily recognizable due to their relatively thick primary and secondary veins, in spite of the leaf margins being nearly always damaged. Some of the leaves reveal toothed margins. Conifers are represented by numerous fragments of leaves. Fragments of branches of Dacrydium vel Halocarpus (description after Fontes and Dutra 2010, originally described as Dacrydium vel Dacrycarpus by Zastawniak, 1981) are usually long, with diamond-shaped twigs (Fig. 4J). Only one poorly preserved leaf imprint of Dicksonia sp. (Fig. 4K) was found (Cunha et al., 2008).

The chemical weathering indices calculated and used in this study are presented in Appendix $1^{*}$. The CIA, CIW and PIA are based on the ratio of a group of mobile oxides to immobile ones (these indices assume that $\mathrm{Al}$ is immobile) and they are interpreted as a measure of the extent of conversion of feldspars to clays. Although CIA ratios calculated for Mount Wawel sediments are typical for low chemical weathering under frosty conditions (CIA: 0.52-0.65) accompanying low maturity values suggest that the CIA values are likely to reflect the high content of fresh, contemporary pyroclastic material supply. Evidences for presence of vegetation indicate warm, non-glacial conditions. Syndepositional volcanism have similar influence on PIA (0.52-0.64) and CIW (0.54-0.65) indices, as it decreases those values. Analysis carried out on volcanic bombs explain and confirm the reason for low values of these indices (CIA: 0.42-0.44; PIA: 0.42-0.44; CIW: 0.43-0.45).

$X$-ray diffraction studies, as well as microscope examination and SEM analyses suggest that laumontite, gismondine and other zeolites are present as weathering products of plagioclase in the upper part of the Mount Wawel Formation.

\section{ADMIRALTY BAY AREA - CYTADELA LOCALITY}

The Middle Eocene Petrified Forest Creek flora (Arctowski Cove Formation) and the Middle-Late Eocene Cytadela flora (Point Thomas Formation) both belong to the Ezcurra Inlet Group (Birkenmajer, 1980, 2003). They occur in a volcanic and volcaniclastic succession with plant detritus and petrified wood (Stuchlik, 1981).

The Cytadela exposure represents the upper part of the Point Thomas Formation. The exposure is composed of two members and demonstrate distinct informal units. The lower member is composed of a complex of andesitic lavas, conglomerates and volcanoclastic sediments with abundant fossil plants, whereas the upper member is composed mainly of andesitic lavas and conglomerates (Mozer, 2012; Fig. 5A).

The fossils occur in volcaniclastic fine-grained sediments, tuffs and tuffites, usually of reworked material of varying thickness. Above the fine-grained sediments with beds and abundant leaves, there are lavas with pillow structures at the base, most likely formed as a result of lava cooling in shallow lakes or ponds with stagnant water (Fig. 5B). The Cytadela leaf flora contains mostly small Nothofagus-type leaves, and pinnately

\footnotetext{
* Supplementary data associated with this article can be found, in the online version, at doi: $10.7306 / \mathrm{gq} .1100$
} 

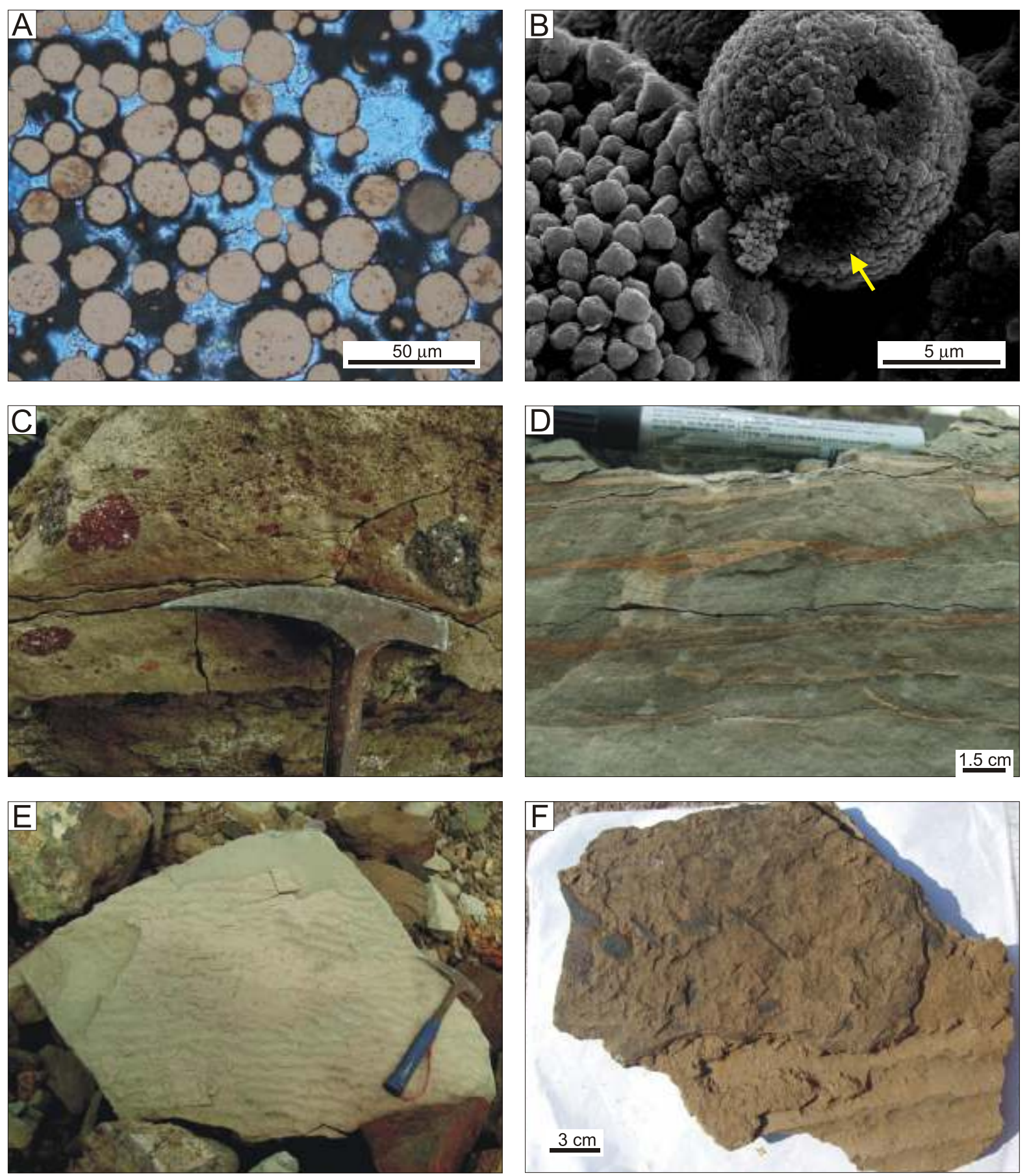

Fig. 2A - framboidal pyrite in sedimentary facies of the Mount Wawel Formation, TLM and RLM images of polyframboidal aggregates; B - pyritic structures associated with framboids in sedimentary facies of the Mount Wawel Formation; pyritic microcapsules showing empty interiors and apertures open towards the pore space (arrow); SEM image; C - typical block of volcanoclastic sedimentary facies from Dragon Glacier Moraine, Mount Wawel Formation, containing horizons of plant detritus; note high content of volcanic bombs; D - details of the vertical accretion strata: small-scale cross bedding and streaky stratification in block on Dragon Glacier Moraine; E - sedimentary structures in the Dragon Glacier Moraine, Mount Wawel Formation - surface of moraine block with asymmetrical wave ripples (the hammer is $32 \mathrm{~cm}$ long); $F$ - highly fragmented plant fossil remains exhibiting an unidirectional orientation and horizon of ripples on a block from the Dragon Glacier Moraine, Mount Wawel Formation

veined leaves of other dicotyledonous types. Among the ferns, a Blechnum-related form is recorded. Poorly preserved fragments of Podocarpaceae are also present (Birkenmajer and Zastawniak, 1989a; Mozer, 2012). This plant fossil assemblage is similar to those described by Askin (1992) and Francis et al. (2009) from other localities of plant beds on KGI. Moreover the fossil plant assemblage from Cytadela is similar to the Dragon
Glacier Moraine flora; the angiosperm leaves being dominated by Nothofagus and the conifers including Araucariaceae (Fig. 5C, D) in addition to Podocarpaceae (Fig. 5E, F). Trunk trees incorporated in lava and tuffs were found (Fig. 6). Impressions of leaves are often damaged, especially at the margins, but usually show distinct primary and secondary veins, which make them easy to recognize. Moreover, sedimentary beds contain- 

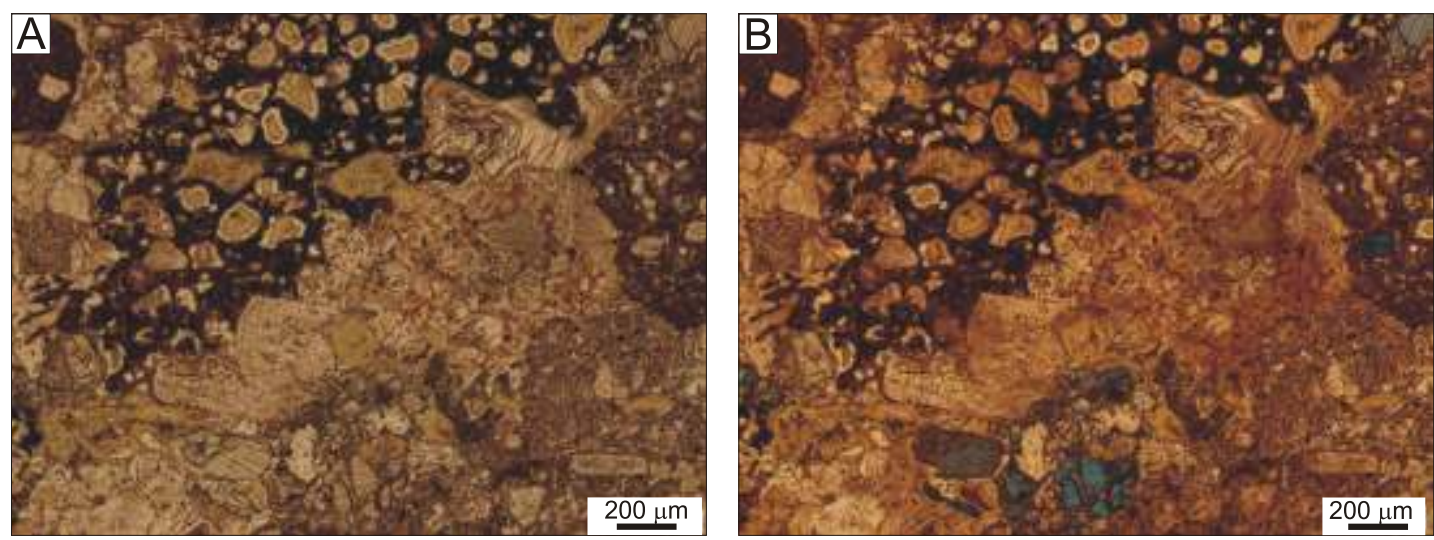

Fig. 3. Thin section of plant-bearing tuffite from Mount Wawel Formation, Dragon Glacier Moraine (A - TLM image; B - RLM image, normal light)

Note content of lithoclasts, altered volcanic glass, opaque minerals, pyroxene crystals and altered plagioclases

ing plant detritus experience direct contact with overlying lava flows, causing thermal alteration and damage (burn or char) of plant material making their identification difficult.

The CIA values obtained from Cytadela from the lower member of the volcaniclastic intercalations within volcanites with abundant plant fossils range from 0.75 to 0.85 . The unweathered basaltic bedrock (lava flows) was used as the reference $(<0.60)$. PIA and CIW also reveal high values, confirming that during this preglacial stage (PGS-1) warm, non-seasonally wet conditions prevailed (PIA values $>0.75$; CIW values $>0.80$ ). The upper member of the Cytadela exposure does not contain plant fossils. It is composed of conglomerates and andesitic lavas with regoliths on their surfaces. Geochemical weathering indices are frequently used in characterizing regoliths by quantifying the intensity of chemical alteration versus stratigraphy (Strømsøe and Paasche, 2011). Lack of variation in the indices among volcanic substratum and sediments in the upper member and a relatively narrow range of low values were recorded. During the second preglacial stage (PGS-2), a climatic change occurs towards deterioration and relatively dry regime (CIA values approximate to 0.60). The CIA, PIA, CIW values of regolith samples are show in Appendix 1.

Primary minerals were identified in the thin sections by optical microscopy; secondary minerals in the weathering products were identified by means of random powder X-ray diffraction. $X$-ray diffraction analysis suggests that clinoptilolite, heulandite and other zeolites are present as weathering products in the upper part of Point Thomas Formation.

The lower member corresponds with an Early-Middle Eocene preglacial phase (PGS-1). It was developed in a terrestrial environment with high volcanic activity, and is characterized by abundant vegetation similar to modern Valdivian forests with domination of Nothofagus and Podocarpaceae. The upper member corresponds with the Middle-Late Eocene preglacial phase (PGS-2), developed during continued volcanic activity in the terrestrial environment and relatively dry and cool climate conditions.

\section{KING GEORGE BAY AREA - LIONS RUMP LOCALITY}

In the King George Bay area, the upper part of the Mazurek Point Formation (Chopin Ridge Group) and Lions Cove Formation (Polonia Glacier Group) were examinated. These units are exposed on Conglomerate Bluff outcrop. The Conglomerate Bluff outcrop is composed predominantly of lapilli tuff and pyroclastic breccia, pyroxene andesite and ashes. Tuffaceous mudstone and sandstone contain plant fossils, as well as coal seams and coaly shales. Unfortunately the majority of the flora is represented by non-diagnostic leaf fragments that prevent even approximate identification. Nothofagus dominated among assemblage of plant macrofossils. Most of the organic matter is difficult to determine and poorly preserved. It is usually found as plant detritus or coal beds and petrified wood. Mountainous landscapes under intensive water erosion (probably caused by the lowering of the erosive base in the Antarctic Peninsula region) formed river canyons filled with conglomerate deposits. An essential part of the Conglomerate Bluff profile represents a large valley eroded in sandstones and mudstones. Conglomerates filling the valley are represented by local clasts deposited under terrestrial conditions by rivers and streams (Fig. 7A) and represent the third preglacial stage (PGS-3). The sedimentary succession underlying the conglomerate is composed mostly of brown tuff-mudrock, green tuff and breccias, and mudrock with coal and wood. These sediments, rich in scattered organic matter and coal are thermally altered on contact with the andesitic lava flow (Fig. 7B). The bottom of the lava flow shows a pillow structure, which suggests cooling of lava in a shallow lake. Thin sections of mudrock associated with the coal, revealed crushed plagioclase crystals with inclusions, surrounded by opaque minerals and organic matter (Fig. 7C).

Weathering indices calculated for the Lions Rump profile, CIA, CIW and PIA, show rather diverse values. High values of indices $(>0.70)$ in the lower part of section suggest relatively advanced chemical weathering. Low and rather narrow ranges of values (around 0.50-0.60) in the upper part of profile confirm the maintenance of volcanic activity and the supply of pyroclastic material and ashes, as well as distinct changes in climate, with deterioration of climate conditions.

The Lions Cove Formation includes the record of sediments directly prior to the onset of glaciation. Conglomerate deposits are covered directly by massive and/or bedded diamictite containing local and exotic clasts related to a new type of activity in the area. Glacial activity reveals ice rafted deposits and diamictites in the Krakowiak Glacial Member of Polonez Cove Formation in King George Bay (Birkenmajer, 2001). During this time the ice sheet reached the edges of the continent and was grounded on a shallow marine shelf, producing icebergs, which supplied exotic material in the form of boulders, gravel and sand. Exotic clasts, mostly non-mafic, seems to have been delivered by the rocks from the Ellsworth and Transantarctic Mountains.

The KGM (Krakowiak Glacier Member) consists largely of diamictite and gravelly sandstone, with minor interbeds and lenses of granule to pebble conglomerate and medium sand- 

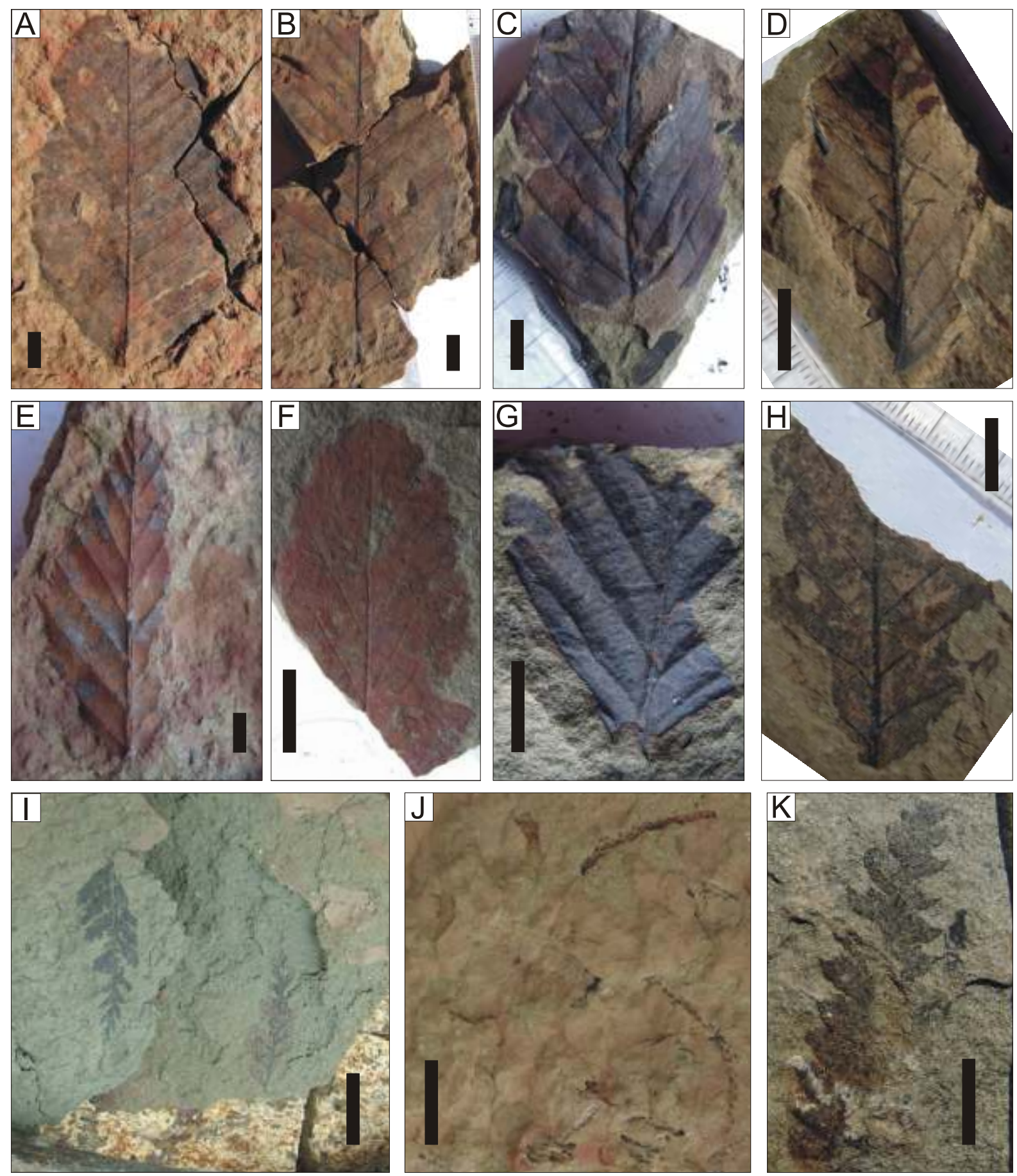

Fig. 4. Selection of plant fossils from Dragon Glacier Moraine, Mount Wawel Formation

A-H - variety of Nothofagus leaf impressions: general view of the leaf and venation pattern; I - impressions of fragmentary fern frond; $\mathbf{J}$ - fragments of twigs of Dacrydium vel Halocarpus (Podocarpaceae) on block surface; $\mathbf{K}$ - poorly preserved imprint of Dicksonia sp.; scale bars in all photos are $1 \mathrm{~cm}$

stone. Pebble to boulder-sized clasts are most commonly subangular or subrounded (Fig. 7D), marine fossils locally are sparse but widely distributed (Troedson and Smellie, 2002). There is general agreement among researchers that age of the KGM should be considered to be at least mid-Oligocene (Troedson and Smellie, 2002), although the latest study on Sr isotopes suggest younger ages for this member (K. Krajewski, pers. comm., 2011). In connection with this $\mathrm{Sr}$ isotope data the highest part of preglacial seems to be not younger than $32 \pm$ $0.5 \mathrm{Ma}$ (Early Oligocene).

\section{DISCUSSION}

A Middle Eocene to Late Oligocene age for the Point Hennequin Group has been suggested by many authors (Pankhurst and Smellie, 1983; Smellie et al., 1984; Zastawniak et al., 1985; Birkenmajer, 1989a, 2003; Dutra, 2004; Fontes and Dutra, 2010), however, a new series of K-Ar datings of the Mount Wawel Formation points to its Eocene age (Z. Pécskay, pers. comm., 2011). A Middle Eocene age for the Mount Wawel 

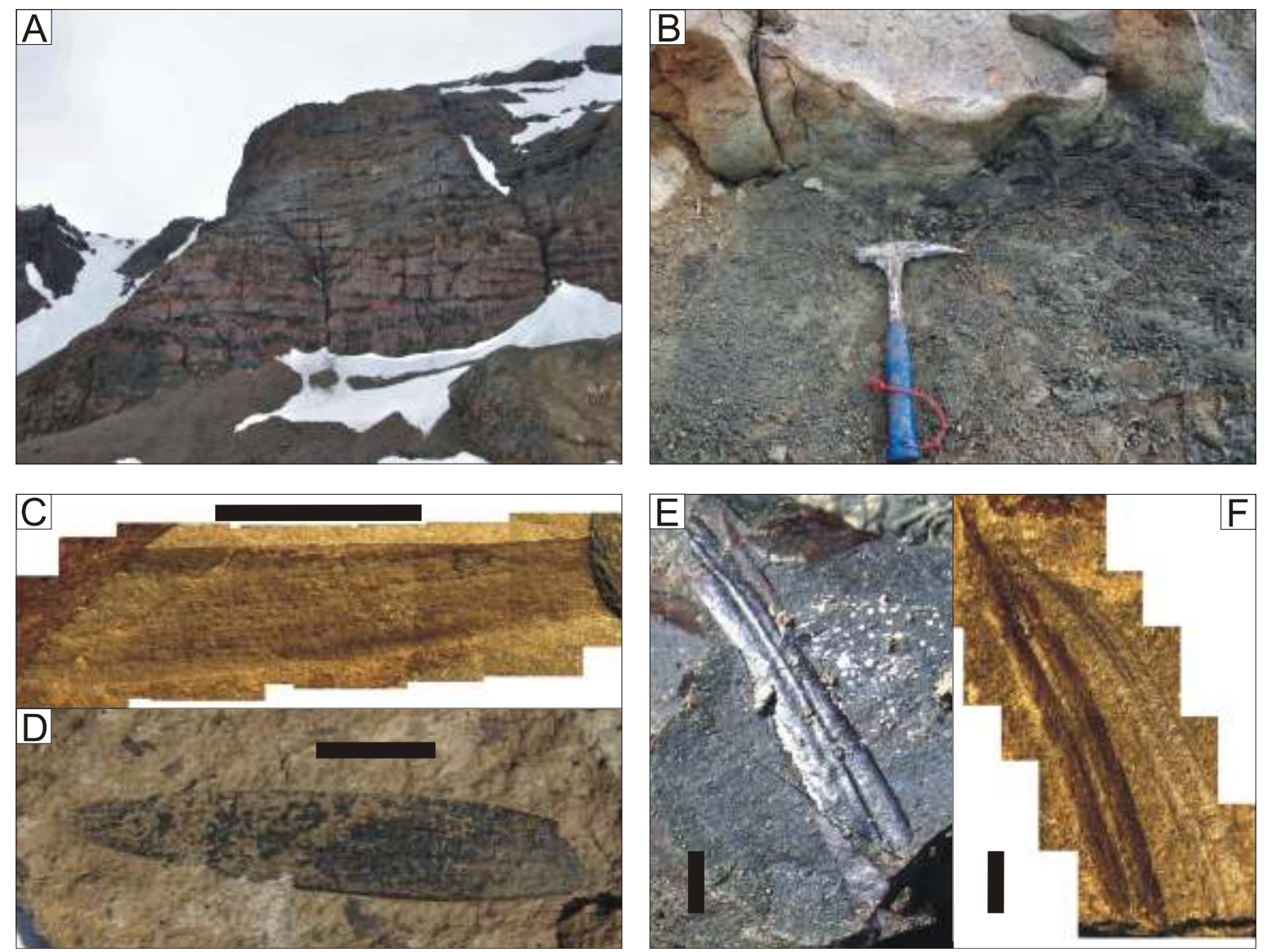

Fig. 5A - general view of Upper Member of Point Thomas Formation at Cytadela; basalt to basaltic andesite lavas with developed regoliths surface; wall is about $150 \mathrm{~m}$ high; B - contact of andesitic lava flow with underlying mudstone/siltstone containing fossil plants, Lower Member of Point Thomas Formation at Cytadela; note pillow structure in the bottom of lava; C, D - fragments of leaf impression of Araucaria, note wide parallel densely-arranged venation (C - specimen from Point Thomas Formation, D - specimen from Mount Wawel Formation), scale bars are $1 \mathrm{~cm}$; E, F lanceolate and elongate podocarp leaves with parallel margins from plant-bearing horizon of Lower Member of Point Thomas Formation at Cytadela, scale bars are $0.5 \mathrm{~cm}$

Formation was proposed by Nawrocki et al. (2011) as a result of $\mathrm{U}-\mathrm{Pb}$ and ${ }^{40} \mathrm{Ar}-{ }^{39} \mathrm{Ar}$ analyses. Taking into account that similar plant beds were found in the Fildes Formation on Fildes Peninsula and dated to be Eocene in age (Poole et al., 2001; Fontes and Dutra, 2010), a similar age of the Point Thomas Formation in Ezcurra Inlet is highly probable (Mozer, 2012). A Middle Eocene age was suggested for the Lions Cove Formation ( $Z$. Pécskay, pers. comm., 2011).

The results show that $\mathrm{KGI}$ experienced a warm, wet, non-seasonal climate during the Paleogene climatic optimum, which persisted until early Middle Eocene time. The latest Late Eocene climate on KGI was cold and relatively dry, possibly with a seasonal snow cover. There is no direct evidence for glacial deposition on KGI during the latest Late Eocene (Upper Member of Point Thomas Formation).

The clastic facies of the Mount Wawel and Point Thomas Formations record sedimentation in local depressions and coastal areas on a young magmatic island arc, with recurrent events of enhanced supply of plant detritus from a forest-covered mountainous landscape. Middle Eocene age floras from King George Island suggest warm to cool temperate climates, generally moist and probably frost-free, although in general the climate trend was towards cooling. After the Early Eocene Climatic Optimum the climate was cold, but vegetation was able to persist, although higher diversity assemblages and thermophytes had disappeared. They were replaced by vegetation that was dominated by several species of the southern beech, Nothofagus in Early and Middle Eocene forests. Along with few ferns and some podocarp conifers, southern beech trees probably grew as shrubby vegetation in most areas. Genus Dacrycarpus (conifers belonging to the Podocarp family) occurs in mountain forests up to $3600 \mathrm{~m}$ a.s.I. in south-east Asia, islands of Melanesia and New Zealand, and only one New Zealand species Dacrycarpus dacrydioides grows in mixed swamp forests (Zastawniak, 1981), whereas Nothofagus forests grow today usually in very humid habitats, mainly in temperate and temperate-cool climates (Zastawniak, 1981; Fontes and Dutra, 2010). The presence of leaves from Araucaria and Nothofagus trees in sediments of Point Thomas Formation suggest that the palaeoenvironmental conditions were not so extreme. The Cytadela fossil plant assemblage indicates a generally warm climate during the Early Eocene. Moist, cool temperate rain forests were present, similar to modern low to mid-altitude Valdivian forests in Southern Chile (Poole et al., 2001; Francis et al., 2009). Assemblages of Nothofagus-podocarpaceous vegetation and other angiosperms grow in temperate climate conditions (Askin, 2000). The presence of Nothofagus species in sediments of the Lions Cove Formation suggest a rather cooling of climate.

Sedimentary structures like asymmetrical wave ripples, small-scale cross bedding and stratification observed in volcaniclastic successions exposed in all outcrops discussed here carried important information about predominant conditions during 


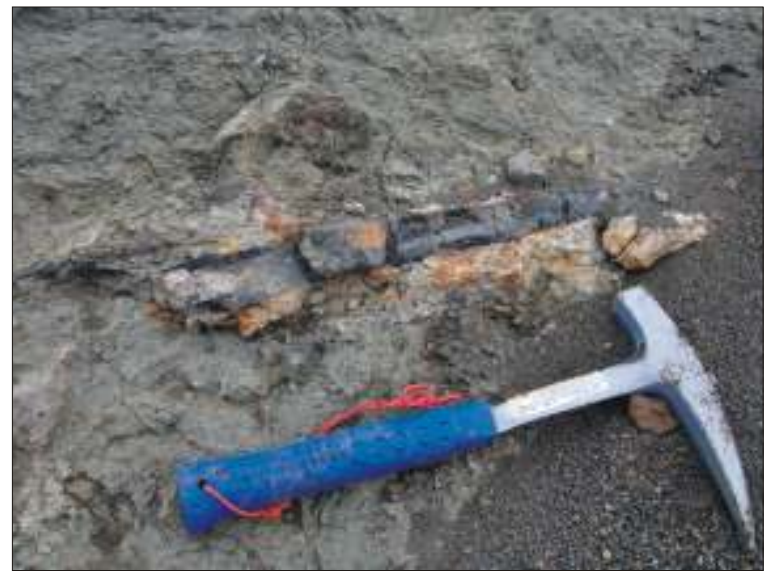

Fig. 6. Partially petrified and charred wood incorporated in the lava flow, Lower Member of Point Thomas Formation at Cytadela

Hammer is $32 \mathrm{~cm}$ long

sedimentation. These structures are the result of deposition in stagnant and flowing water environments with recurrent pulses of increased supply of plant material. The fossils from Cytadela exposure occur in sediments that represent lacustrine - bog and marsh facies, indicating a low energy environment.
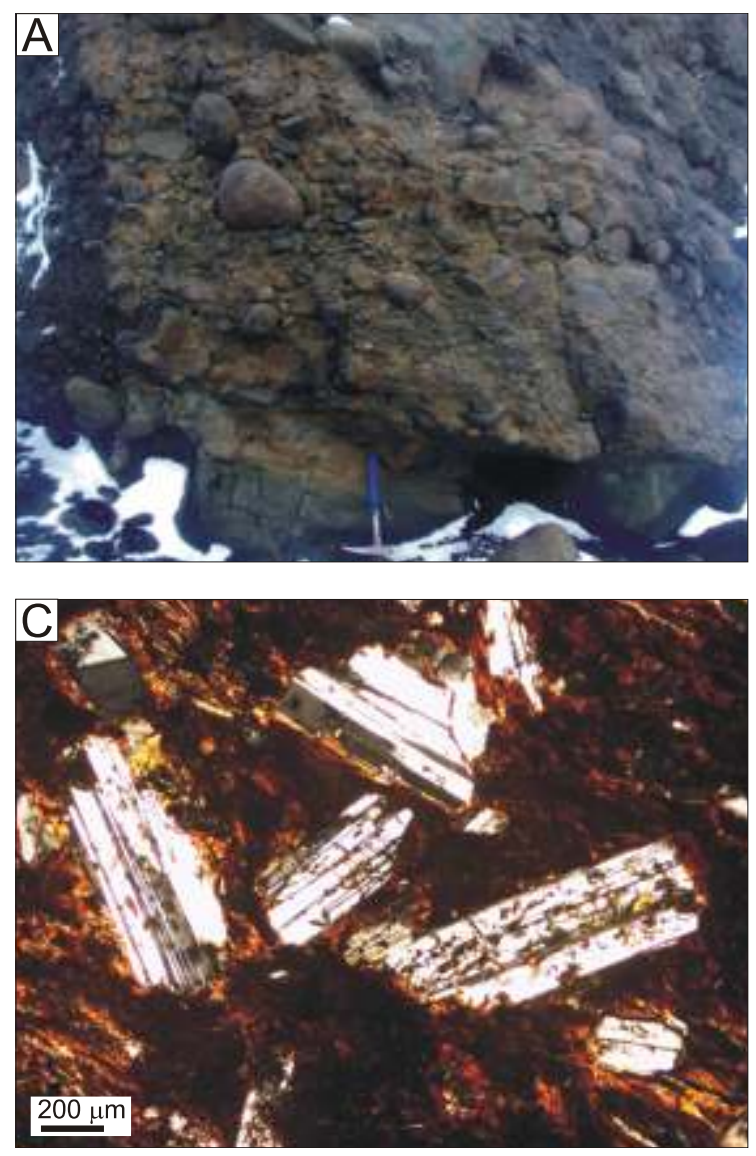

Fig. 7. Details of Lions Rump - Conglomerate Bluff exposure

A - valley eroded in sandstone and mudstone, filled by conglomerate; note the degree of clasts roundness; B - contact of andesitic lava flow with underlying mudstone/siltstone containing fossil plants and coal; note pillow structure in the bottom of lava; $\mathbf{C}$ - thin section of basaltic tephras containing plant detritus and coal seams; note crushed plagioclases crystals with inclusions; TLM and RLM image; D - exotic ice-rafted clasts in coarse sediments of the Krakowiak Glacier Member, Polonez Cove Formation; the hammer is $32 \mathrm{~cm}$ long

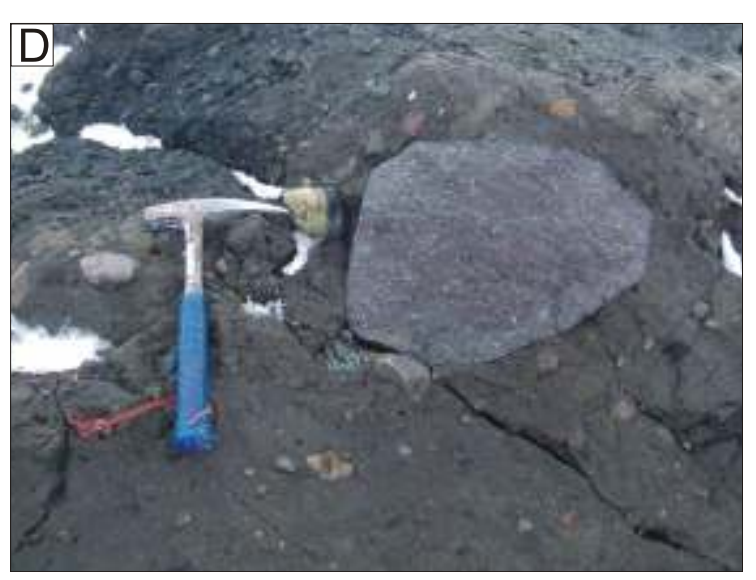
pyrite framboids suggest that their formation involved intermediate precipitates of amorphous or poorly ordered iron monosulphides, followed by crystallization of the mineral phase (Mozer, 2010). In addition, the abundance of authigenic pyrite in clastic facies suggests that there was a supply of marine or mixed marine-volcanic sulphates to the sedimentary environments of the arising arc islands.

Weathering indices of sedimentary rocks were used to provide information about volcanic activity and climatic conditions of the area. High average CIA, PIA and CIW values of Lower Member from Cytadela demonstrate the predominance of chemical weathering under humid and warm conditions. It seems to reflect intensive and advanced weathering processes suggesting warm and ice-free conditions during Early to Middle Eocene. Lack of variation in the indices among volcanic substratum and sediments in upper member suggests a modification and deterioration of palaeoenvironmental conditions during Middle-Late Eocene. The relatively narrow range of low values points to a predominance of physical weathering under progressively colder conditions. During the second preglacial stage (PGS-2), a climatic change occurs towards a frost-prone and relatively dry regime. Low values of CIA from Wawel sediments reflect the high contents of fresh, contemporary volcanic debris/pyroclastic material supply. Sediment maturity was low, suggesting little sediment recycling and deposition relatively close to source. Floral evidence indicates that this period of warmth also coincided with

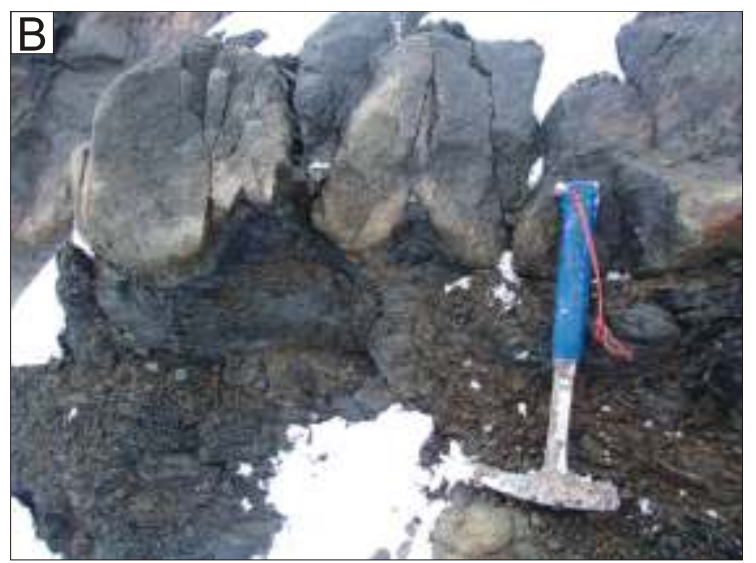


the beginning of a new regime. The relatively low average of the values of weathering indices of the Upper Member from Cytadela point at the deterioration of climate conditions and domination of physical weathering. Values of weathering indices from Lions Rump are diverse; being rather high in the lower part of the section, pointing at relative chemical weathering (low values are caused by supply of volcanic material), and are rather low in the upper part of the section, pointing at the cooling of the climate. By earliest Oligocene times, there is no doubt that ice was present on Antarctica with sediments including exotic clasts indicative of iceberg rafting. The unquestionable record of glacial activity is registered in sedimentary rocks in the Krakowiak Glacier Member (Polonez Cove Formation) of at least mid-Oligocene age. Glacio-marine deposits of the Polonez Cove Formation record ice sheet fluctuation and ice-rafting in a shallow marine environment. Exotic clasts were transported from the centre of the Antarctic continent (Ellsworth Mountains and Transantarctic Mountains).

The Eocene of KGI, like the entire Antarctic Peninsula is marked by diverse floras and a general shift from conifer-dominated forest to Nothofagus-dominated vegetation in the coastal high latitudes. Calculated values of different weathering indices, petrographic analysis of thin sections as well as XRD analyses from the $\mathrm{KGI}$ succession provide valuable information concerning Eocene climatic conditions.

\section{CONCLUSIONS}

Evidence from both the rocks and the fossil plants from KGI area play a significant role in understanding the biodiversity and palaeoecology, including palaeoclimate, at southern high latitudes during the transitional Cenozoic period. That time was a final phases of global tectonic and climatic reorganization for the entire Earth. Vegetation types recorded from KGI is similar to that of the present Valdivian rainforests of southern Chile. The gradual decrease of biodiversity and temporary extinction at the end of Eocene might be observed in the palaeobotanical record. Together with results of sedimentological and petrological observations, as well as geochemical analysis of sedimentary rocks succession, it permits to identify three preglacial stages that directly preface development of glacial conditions on Antarctic continent. These pre-glacial palaeoclimatic stages (PGS-1-PGS-3) documented climate cooling trends, recorded in terrestrial environment that properly corresponds with global greenhouse-icehouse transition, known from marine record (Zachos et al., 2001, 2003, 2008).

The first designated unit of the preglacial stage (PGS-1) is characterized by Valdivian-type forests developed in terrestrial environment. Evidence of this stage can be found in the Arctowski Cove Formation, in the lower part of the Point Thomas Formation at Cytadela exposure and in the Mount Wawel Formation. It correlates with the Early Eocene Climatic Optimum, known from the oceanic record and the Early Eocene warm phase observed in La Meseta Formation on Seymour Island (Doktor et al., 1996; Dingle and Lavelle, 1998; Dingle et al., 1998; Poole et al., 2003; Francis et al., 2008).

The second preglacial stage (PGS-2) is a continuation of volcanic activity of the mixed effusive-explosive style under conditions of a dryer climate. Volcanic landforms composed of agglomerates and tuffaceous deposits intercalated with lava flows tipped by weathering surfaces and regoliths formed as a result of these conditions. The record of this stage can be found in the upper part of Point Thomas Formation at Cytadela outcrop.

Third preglacial stage (PGS-3) is characterized by the cooling of climate and humid conditions in an active volcanic setting and contributed to water erosion of mountainous landscape, formation of river canyons and valleys, and their infilling with conglomeratic deposits. Evidence of this stage can be found in the upper part of Lions Cove Formation at Lions Rump.

The next stage defined in this palaeoclimatic scheme is a result of rapid progradation of Antarctic ice-sheet on the volcanic arc and partial flooding of mountain landscape associated with a marine transgression. It no longer belongs to preglacial and represent a member of glacial stage (GS-1). The onset of glaciation is dated at $32 \pm 0.5 \mathrm{Ma}$ and was found in a lower part of the Polonez Cove Formation and determines moment when ice-sheet reach edge of Antarctic continent. Sediments of this stage cover preglacial units and present a record of the beginning of glacial history on KGI.

Acknowledgments. Paper carried out with logistic support of Polish Antarctic Station Henryk Arctowski within ACE program (Antarctic Climate Evolution). I am grateful to the reviewers Professor T.L. Dutra, Dr V. Bowman, and anonymous reviewer for constructive reviews and critical remarks. I also thank Professor E. Zastawniak-Birkenmajer (W. Szafer Institute of Botany PAS) for kind help in flora analysis.

\section{REFERENCES}

Askin R.A. (1992) Late Cretaceous-early Tertiary Antarctic outcrop evidence for past vegetation and climates. Antarctic Research Series, 56: 61-73.

Askin R.A. (2000) Spores and pollen from the McMurdo Sound erratics, Antarctica. Antarctic Research Series, 76: 161-181.

Askin R.A., Spicer R.A. (1995) The Late Cretaceous and Cenozoic history of vegetation and climate at northern and southern high latitudes: a comparison. In: Effects of Past Global Change on Life, Panel on Effects on Past Global Change on Life, edited by the Board on Earth Sciences and Resources, Commission on Geosciences, Environment, and Resources, National Research Council, National Academy Press, Washington: 156-173.

Birkenmajer K. (1980) Tertiary volcanic-sedimentary succession at Admiralty Bay, King George Island (South Shetland Islands, Antarctica). Studia Geologica Polonica, 64: 8-65.

Birkenmajer K. (2001) Mesozoic and Cenozoic stratigraphic units in parts of the South Shetland Islands and Northern Antarctic
Peninsula (as used by the Polish Antarctic Programmes). Studia Geologica Polonica, 118: 5-188.

Birkenmajer K. (2003) Admiralty Bay, King George Island (South Shetland Islands, West Antarctica): a geological monograph. Studia Geologica Polonica, 120: 5-73.

Birkenmajer K., Zastawniak E. (1986) Plant remains of the Dufayel Island Group (Early Tertiary?), King George Island, South Shetland Islands (West Antarctica). Acta Palaeobotanica, 26 (1-2): 33-54.

Birkenmajer K., Zastawniak E. (1989a) Late Cretaceous-Early Tertiary floras of King George Island, West Antarctica: their stratigraphic distribution and palaeoclimatic significance. Geological Society Special Publications, 47: 227-240.

Birkenmajer K., Zastawniak E. (1989b) Late Cretaceous-Early Neogene vegetation history of the Antarctic Peninsula sector, Gondwana break-up and Tertiary Glaciations. Bulletin of the Polish Academy of Sciences, Earth Sciences, 37 (1-2): 63-88. 
Cunha M.B., Dutra T.L., Cardoso N. (2008) Uma Dicinsoniaceae fértil no Eoceno da llha King George, Península Antárctica. Journal of Geosciences, 1 (4): 1-13.

Dingle R.V., Lavelle M. (1998) Late Cretaceous-Cenozoic climatic variations of the northern Antarctic Peninsula: new geochemical evidence and review. Palaeogeography, Palaeoclimatology, Palaeoecology, 141: 215-232.

Dingle R.V., Marensi S.A., Lavelle M. (1998) High latitude Eocene climate deterioration: evidence from the northern Antarctic Peninsula. Journal of South American Earth Sciences, 11 (6): 571-579.

Doktor M., Gaździcki A., Jerzmańska A., Porębski S.J., Zastawniak E. (1996) A plant-and-fish assemblage from the Eocene La Meseta Formation of Seymour Island (Antarctic Peninsula) and its environmental implications. Palaeontologia Polonica, 55: 127-146.

Duan W., Cao L. (1998) Late Palaeogene palynoflora from Point Hennequin of the Admiralty Bay, King George Island, Antarctica with reference to its stratigraphical significance. Chinese Journal of Polar Science, 9 (2): 125-132.

Dutra T.L. (2001) Paleoflora da ilha 25 de Mayo (King George Island), Península Antárctica: contribuição à paleogeografia, paleoclima e para a evolução de Nothofagus. Asociación Paleontológica Argentina, Publicación Especial, 8: 29-37.

Dutra T.L. (2004) Paleofloras de Antártica e sua relaçno com os eventos tectônicos e paleoclimáticos nas altas latitudes do sul. Revista Brasileira de Geociências, 34 (3): 401-410.

Elliot D.H. (1988) Tectonic setting and evolution of the James Ross Basin, northern Antarctic Peninsula. GSA Memoir, 169: 541-555.

Fedo C.M., Nesbitt H.W., Young G.M. (1995) Unravelling the effects of potassium metasomatism in sedimentary rocks and paleosols, with implications for paleoweathering conditions and provenance. Geology, 23: 921-924.

Fontes D., Dutra T.L. (2010) Paleogene imbricate-leaved podocarps from King George Island (Antarctica): assessing the geological context and botanical affinities. Revista Brasileira de Paleontologia, 13 (3): 189-204.

Francis J.E., Poole I. (2002) Cretaceous and early Tertiary climates of Antarctica: evidence from fossil wood. Palaeogeography, Palaeoclimatology, Palaeoecology, 182: 47-64.

Francis J.E., Ashworth A., Cantrill D.J., Crame J.J., Howe J., Stephens R., Tosolini A.M., Thorn V. (2008) 100 million years of Antarctic climate evolution: evidence from fossil plants. In: Antarctica: a Keystone in Changing World (eds. A.K. Cooper, P.J. Barrett, H. Stagg, B. Storey, E. Stump, W. Wise and the 10th ISAES): 19-27. The National Academies Press.

Francis J.E., Marenssi S., Levy R., Hambrey M., Thorn V.T., Mohr B., Brinkhuis H., Warnaar J., Zachos J., Bohaty S., Deconto R. (2009) From Greenhouse to Icehouse - the Eocene/Oligocene in Antarctica. In: Antarctic Climate Evolution (eds. F. Florindo and M. Seigert). Elsevier, 8: 309-368.

Harnois L. (1988) The CIW index - a new chemical index of weathering. Sedimentary Geology, 55: 319-322.

Hunt R.J., Poole I. (2003) Palaeogene West Antarctic climate and vegetation history in light of new data from King George Island. GSA Special Paper, 369: 395-412.

Kellner A.W.A., Dutra T.L., Carvalho M.A., Ramos R.R.C., Grillo O.N., Silva H.P., Riff D., Romano P.S. (2007) First record of fossils leaves from the Keller Peninsula, King George Island, Antarctica. In: Paleontologia: Cenários de Vida, vol. 1 (eds. I.S. Carvalho, R.C.T. Cassab, C. Schwanke, M.A. Carvalho, A.C.S. Fernandes, M.A.C. Rodriguez, M.S.S. Carvalho, M. Arai and M.E.Q. Oliveira): 627-635. Interciência

Kennett J.P., Baker P.F. (1990) Latest Cretaceous to Cenozoic climate and oceanographic developments in the Weddell Sea, Antarctica: an ocean-drilling perspective. Proceedings of the Ocean Drilling Program, Scientific Results, 113: 937-960.

Li H.M. (1992) Early Tertiary palaeoclimate of King George Island, Antarctica-evidence from the Fossil Hill flora. Recent Progress in Antarctic Earth Sciences (eds. Y. Yoshida et al.), Tokyo, Terra Scientific Publishing Company (Terrapus): $371-375$.

Lucas R.C., Lacey S.W. (1981) A permineralized wood flora of probable Early Tertiary age from King George Island, South Shetland Islands. British Antarctic Survey Bulletin, 53: 147-151.
Mozer A. (2010) Authigenic pyrite framboids in sedimentary facies of the Mount Wawel Formation (Eocene), King George Island, West Antarctica. Polish Polar Research, 31 (3): 255-272.

Mozer A. (2012) Pre-glacial sedimentary facies of the Point Thomas Formation (Eocene) at Cytadela, Admiralty Bay, King George Island, West Antarctica. Polish Polar Research, 33 (1): 41-62.

Nawrocki J., Pańczyk M., Williams I.S. (2011) Isotopic ages of selected magmatic rocks from King George Island (West Antarctica) controlled by magnetostratigraphy. Geological Quarterly, 55 (4): 301-322.

Nesbitt H.W., Young G.M. (1982) Early Proterozoic climates and plate motions inferred from major element chemistry of lutites. Nature, 299: 715-717.

Pankhurst R.J., Smellie J.L. (1983) K-Ar geochronology of the South Shetland Islands, Lesser Antarctica: apparent lateral migration of Jurassic to Quaternary island arc volcanism. Earth and Planetary Science Letters, 66: 214-222.

Panti C., Pujana R.R., Zamaloa M.C., Romero E.J. (2012) Araucariaceae macrofossil record from South America and Antarctica. Alcheringa, 36 (1): 1-22.

Poole I., Hunt R.J., Cantrill D.J. (2001) A fossil wood flora from King George Island: ecological implications for an Antarctic Eocene vegetation. Annals of Botany, 88: 33-54.

Poole I., Mennega A.M.W., Cantrill D.J. (2003) Valdivian ecosystems in the Late Cretaceous and Early Tertiary of Antarctica: further evidence from myrtaceous and eucryphiaceous fossil wood. Revue of Palaeobotany and Palynology, 124: 9-27.

Sijp W.P., England M.H., Toggweiler J.R. (2009) Effect on ocean gateway changes under greenhouse warmth. American Meteorological Society, 22: 6639-6652.

Smellie J.L., Pankhurst R.J., Thomson M.R.A., Davies R.E.S. (1984) The geology of the South Shetland Islands. VI.: Stratigraphy, geochemistry and evolution. British Antarctic Survey Scientific Reports, 87.

Strømsøe J.R., Paasche Ø. (2011) Weathering patterns in high-latitude regoliths. Journal of Geophysical Research, 116.

Stuchlik L. (1981) Tertiary pollen spectra from the Ezcurra Inlet Group of Admiralty Bay, King George Island (South Shetland Islands, Antarctica). Studia Geologica Polonica, 72: 109-108.

Topographic Map (Satellite Image Map, 2001). Scale 1:100 000. King George Island, South Shetland Islands. Publisher: Institut für Geographie, Universität Freiburg, Germany and Laboratório de Pesquisas Antárticas e Glaciológicas. Univeridade Federal do Rio Grande do Sul, Brasil. Freiburg, November 2001.

Troedson A.L., Smellie J.L. (2002) The Polonez Cove Formation of King George Island, Antarctica: stratigraphy, facies and implications for mid-Cenozoic cryosphere development. Sedimentology, 49: 277-301.

Zachos J.C., Shackleton N.J., Revenaugh J.S., Pälike H., Flower B.P. (2001) Climate response to orbital forcing across the Oligocene-Miocene boundary. Science, 292: 274-278.

Zachos J.C., Wara M.W., Bohaty S., Delaney M.L., Rose-Petrizzo M.R., Brill A., Bralower T.J., Premoli-Silva I. (2003) A transient rise in tropical sea surface temperature during the PaleoceneEocene Thermal Maximum. Science, 302: 1551-1554.

Zachos J.C., Dickens G.R., Zeebe R.E. (2008) An early Cenozoic perspective on greenhouse warming and carbon-cycle dynamics. Nature, 451: 279-283.

Zastawniak E. (1981) Tertiary leaf flora from the Point Hennequin Group of King George Island (South Shetland Islands, Antarctica). Preliminary report. Studia Geologica Polonica, 72: 97-108.

Zastawniak E. (1990) Late Cretaceous leaf flora from King George Island, West Antarctica. In: Palaeofloristic and Palaeoclimatic changes in the Cretaceous and Tertiary (eds. E. Knobloch and Z. Kvaček). Proceedings of the Symposium Prague, 1989, 81-85.

Zastawniak E.(1998) Plant vegetation in the Late Cretaceous and Tertiary of West Antarctica (in Polish with English summary). Kosmos 47 (4): 409-416.

Zastawniak E., Wrona R., Gaździcki A., Birkenmajer K. (1985) Plant remains from the top part of the Point Hennequin Group (Upper Oligocene), King George Island (South Shetland Islands, Antarctica). Studia Geologica Polonica, 81: 143-164. 